\title{
Thermal and Physicochemical Properties of Some Starchy Foods: Yam (Dioscorea rotundata), Cocoyam (Xanthosoma sagittifolium) and Plantain (Musa paradisiaca)
}

\author{
Oluwamukomi M. O.*, Akinsola O. O. \\ Department of Food Science \& Technology, Federal University of Technology, Nigeria
}

Copyright (C) 2015 Horizon Research Publishing All rights reserved.

\begin{abstract}
The thermal and physicochemical characteristics of yam species (Dioscorea rotundata), plantain species (Musa paradisiaca) and cocoyam species (Xanthosoma sagittifolium) were studied. Yam, cocoyam tubers and fingers of plantains were processed into flour for the determination of quality characteristics. The moisture content of the samples ranged from $5.6-8.4 \%$ with the plantain flour having the lowest value. The protein content of yam was the highest (3.2\%) while the plantain flour was the lowest $(2.07 \%)$ although with the highest carbohydrate content of about $88.34 \%$. Values for ash content ranged between $1.93 \%$ and $2.82 \%$ with the lowest value obtained for plantain and the highest for cocoyam. The wettability values ranged from 40.67- 106.67 secs being highest in the plantain flour. Angle of repose was highest for plantain $\left(35.67^{\circ}\right)$. The amylose content was highest in yam (35.92\%) while plantain gave the least $(25.53 \%)$. Cocoyam has the highest solubility at $45^{\circ} \mathrm{C}$ and the highest also at $90^{\circ} \mathrm{C}$, the same thing was observed in its swelling power. Yam gave the least value for solubility. Pasting temperature ranged from $48.01-49.51^{\circ} \mathrm{C}$ with highest in cocoyam flour. Peak time ranged from 4.97 min to $5.15 \mathrm{~min}$ while plantain had the highest value. Peak viscosity ranged between 272.47 and 373.87 RVU being lowest for cocoyam and highest for yam flour. The relatively higher pasting temperatures required, and the lower pasting viscosities make cocoyam suitable for producing weaning foods and other products that require low viscosity. Pasting properties of cocoyam revealed relatively higher thermal and mechanical stability which will make it a good ingredient for processed foods, especially those that require thermal sterilization.
\end{abstract}

Keywords Physicochemical, Thermal, Properties, Pasting, Yam, Cocoyam, Plantain

\section{Introduction}

Tropical root and tuber crops, of which plantain, yam and cocoyam are important representatives, constitute an under-exploited resource of developing countries. Many of the developing world's poor farmers and food insecure people are highly dependent on root and tuber crops as a contributing, if not the principal, source of food, nutrition, and cash income [1]. Plantain is an example of the major tuber crop in the tropical and subtropical zones of the world. It is an important food crop because it provides a high percentage of carbohydrate. Nigeria produces about 2.11 million metric tonnes annually. However, about 35 to $60 \%$ post-harvest losses had been reported and attributed to lack of storage facilities and inappropriate technologies for food processing [2]. Environmental factors such as temperature, humidity, light intensity and air composition of the storage environment have been reported to affect the storability of harvested plantains [3]. It is therefore essential to consider its preservation and processing as a means to minimize wastage resulting from post-harvest activities, handling and storage. Past research efforts have been towards improvement of the traditional method of producing plantain flour by blanching [4]. However, there is limited information on the relative effects of this process improvement on the physicochemical properties of the resulting flour and the reconstituted food products [5].

Yam is a seasonal crop and most available during its harvesting period, but scarce and expensive during its planting and growing seasons [6]. The storage life of yams is, however, limited to their dormancy period after which they begin to sprout and quickly lose their dietary value. The tubers are stored under different conditions at the various growing areas. In principle, they must be stored in an accessible, adequately ventilated area protected against direct sunlight [1]). Yam, like other root and tuber crops such as cassava and taro, suffers considerable postharvest losses which can be as high as 60\%, [7], and [8]. Yam, apart from providing basic food security and income, is a source of nutrition for millions of people. It is a rich source of carbohydrate and also contributes to vitamins and minerals especially where it is consumed in large quantities. Generally the ash content of yam gives an indication of its mineral status [9]. Yam is also a good source of manganese, 
a rare mineral that helps with carbohydrate metabolism and also acts as a cofactor in number of enzymes important in energy production and antioxidant defenses. It also contains traces of vitamin B- complex [10]. An amount of $1.44 \mathrm{mg} / 100 \mathrm{~g}$ of $\mathrm{b}$-carotene, a precursor of vitamin $\mathrm{A}$, has been reported in Igangan a cultivar of D. cayenensis [9]. Yam starches are reported to contain 3 to 4 times as much phosphorus as those found in cassava and aroids [11]. Peroni et al. [12] reported higher amounts of phosphorus in yam $(0.022 \%)$ compared to other tropical root and tuber crops such as cassava and sweet potato.

Cocoyam (Xanthosoma sagittifolium) is also found as an important crop only in warm, humid forest areas because of their need for high annual rainfall and a long wet season. They thrive well on imperfectly drained soils and are not damaged by occasional flooding. Taro (Colocassia esculenta) is a tropical tuber crop largely produced for its underground corms and consumed in tropical areas of the world. Taro has been reported to have $70-80 \%$ starch with small [13]. Taro is also rich in gums (mucilage) and up to $9.1 \%$ crude taro mucilage has been extracted from taro corms. Because of the small sizes of its starch granules, taro is highly digestible, and as such has been reported to be used for the preparation of infant foods in Hawaii and other Pacific islands. Despite their nutritional, industrial and health importance, cocoyam, yam and plantain have not gained sufficient research attention to enhance its potential. In addition to this fact, they have a high post-harvest loss due to their high moisture content. As such these tubers have a poor position on the food security profile of countries. In fact, it has been estimated that there is an average of $30 \%$ loss during storage of these tubers, and that this portion could resolve starvation problems in non-developed countries.

In order to minimize tuber losses, they must be converted from perishable to non-perishable through food processing operations. Since the transformation into starch or flour will decrease losses after the tubers have been harvested, value added processes such as drying and milling may be useful in order to obtain flours and starches from these tubers. The principal component of these tropical root and tuber crops is starch, which is increasingly becoming an important raw material for the food and non-food industries worldwide. Despite being rich in starch, tropical root and tuber crops have remained underutilized, though starch from these crops could be used in different industrial applications. The current industrial demand for starch is being met by a restricted number of crops mainly corn, potato and wheat [14]. Consequently, the world starch market is dominated by starches from these three crops. In order to increase the competitiveness of starches from tropical root and tuber crops on the world markets, unveiling of the characteristic properties of starches from these crops is required [15].

Starch is one of the most important products to man. It is an essential component of food providing a large proportion of daily calorie intake for both humans and livestock. Starch alone accounts for $60-70 \%$ of calorie intake of humans. Besides its nutritive value, starch is a very versatile raw material with a wide range of applications in food, feed, pharmaceutical, textile, paper, cosmetic and construction industries. In the food industry, starch is used as a thickener, a filler contributing to the solid content of soups, a binder to consolidate the mass of food and prevent it from drying out during cooking, and as a stabilizer. Non-food applications of starch include; adhesives in the paper and packaging industry, match-head binders in explosives, concrete block binders and plywood adhesive in the construction industry, fabric finishing and printing in the textile industry, pill coating and dispersing agents in pharmaceuticals, sintered metal adhesive and foundry core binders in metals, and manufacture of biodegradable plastics and dry cell batteries [16]. These applications depend on the functional properties of the starchy foods such as gelatinization, pasting, retrogradation, water absorption capacity, swelling power, and solubility which vary considerably from one botanical source to another [12], and with variety and environmental conditions $[17,18])$. The functional properties are also dependent on composition and structures of the starches in the roots which include amylose/amylopectin ratio, granular size, and molecular weight of the starches and chain length distribution of amylopectin [19]. Therefore, unraveling the potential of starchy foods for use in the food and non-food industries calls for a better understanding of their unique physicochemical, functional and thermal properties. The objectives of this study therefore are to produce flours from some starchy foods (yam, cocoyam and plantain) and determine their thermal and physicochemical properties of importance in food processing.

\section{Materials and Methods}

Yam (Dioscorea rotundata), Cocoyam (Xanthosoma sagittifolium) and Plantain (Musa spp.) were obtained from the Oba market Akure. The materials were sorted, washed, peeled and sliced into $1 \mathrm{~mm}$ thickness as described by Oluwalana and Oluwamukomi [3]. The slices were soaked in $200 \mathrm{ppm}$ sodium metabisulphite solutions for 10 minutes, drained, blanched at $100^{\circ} \mathrm{C}$ for 5 minutes and then dried at $60^{\circ} \mathrm{C}$ for 48 hours and then dry milled into powder using Marlex Blender (Electro line Model IS 4780, CM/L 7902804) to obtain the flours. The flours were packaged in a HDPE film and kept in a refrigerator until ready for use.

\subsection{Physical Properties}

The following physical properties were determined on the flours: Starch swelling index was determined by the modified method of Ukpabi and Ndimele [20]. Twenty five (25) grams of the flour was measured into a $210 \mathrm{ml}$ measuring cylinder noting its original volume. $150 \mathrm{ml}$ of cold water was added and allowed to stand for 4 hours before observing the final volume of swelling. Swelling index is the final volume divided by the original volume. The reconstitution index was determined according to the method described by Banigo and Akpapunam [21]. 100ml of boiling water was mixed with $10 \mathrm{~g}$ of the flour for $90 \mathrm{sec}$ in a $250 \mathrm{ml}$ graduated cylinder. Ratio of the volume of sediment 
recorded after 10minutes to the original volume served as the index of reconstitution. Wettability of flour was determined according to the method reported by Armstrong et al. [22] One gram of the sample is allowed to drop freely from $15 \mathrm{~mm}$ level above $200 \mathrm{ml}$ water in a measuring cylinder and the time it took for the particles to sink totally was noted. The time was recorded as the wettability power of the sample. The method of Ukpabi and Ndimele [20] was used to determine the packed and loosed bulk densities of the flour samples. Loosed bulk density was determined using a small cylindrical glass container of known weight and volume. The sample was poured into the container, leveled with a spatula and weighed. Tapping or knocking of the cylinder was avoided at this stage. The bulk density calculated here was referred to as 'poured', 'unsettled' or 'loosed' bulk density. The bulk density was the difference in weight of the container divided by the volume in $\mathrm{g} / \mathrm{ml}$. For the Packed bulk density the same container was used but the 'settled' or 'packed' density after compacting was obtained by tapping the cylinder gently unto the wooden surface by dropping it from a height of $1.2 \mathrm{~cm}$ once per second, adding more flour until the cylinder is full and the top is scraped off with a spatula to obtain uniform volume. The density is calculated as above. The mean particle diameter (dp) was estimated by the method of Geldart [23]. Water holding capacity of the samples was determined as described by Medcalf and Gillies [24]. Average granule diameter $(\mu)$ of flour samples were measured microscopically as described by Numfor and Noubi [25]. The porosity (n) was determined by the method of Atkinson [26]. The angle of repose was calculated from the ratio of the height to the base radius of the heap formed using the method of Chen and Lu. [17]. Gel strength of 'amala', a local dough, obtained from hot water reconstitution of the flour samples was determined using Precision Cone Penetrometer (Bench top model, Pioden Controls Ltd., UK to measure the depth of penetration in $\mathrm{mm}$, the softer the gel and the lower the gel strength and the higher the length of penetration. Some quantity of freshly prepared reconstituted dough was scooped into the standard cup attached to the penetrometer. Upon cooling, the centre of the cup was positioned perpendicular to the falling probe of the penetrometer. The probe was finally released to fall freely from a standard distance to penetrate into the product in the cup. The total depth of penetration of the probe was then read on the penetrometer scale and the reading, expressed in millimeter (mm), was taken as an index of the product softness or strength.

\subsection{Thermal Properties}

The pasting properties of the samples (yam, cocoyam and plantain) flours were assessed in the Rapid Visco Analyzer (RVA) (Model RVA 3D+, Newport Scientific Australia) according to RVA Manual, Newport Scientific [27]. $2.5 \mathrm{~g} \mathrm{~A}$ flour sample $(2.5 \mathrm{~g})$ was weighed into a dried empty canister; then $25 \mathrm{~mL}$ of distilled water was dispensed into the canister containing the sample. The solution was thoroughly mixed and the canister well fitted into the RVA as recommended. The slurry was heated from $50-95^{\circ} \mathrm{C}$ with a holding time of 2 min followed by cooling to $50^{\circ} \mathrm{C}$ with 2 min holding time. The rate of heating and cooling was at a constant rate of $11.25^{\circ} \mathrm{C}$ per min. Peak viscosity, trough, breakdown, final viscosity, set back, peak time and pasting temperature was read from the pasting profile with the aid of thermocline for windows software connected to a computer. The viscosity was expressed in terms of Rapid Visco Units (RVU), which is equivalent to 10 centipoises

The apparent amylose content was determined by the method of Farhat et al. [28] with modifications. Starch Solubility and The swelling power were determined according to the methods of Sasaki et al. [29]. About $1.0 \mathrm{~g}$ of samples accurately weighed and quantitatively transferred into a clear dried test tube and re-weighed $\left(\mathrm{w}_{1}\right)$. The flour/starch was then dispersed in $50 \mathrm{~cm}^{3}$ of distilled water using a mixer. The resultant slurry was heated at the desired temperature $\left(65,75,85\right.$ and $\left.95^{\circ} \mathrm{C}\right)$ for $30 \mathrm{~min}$ in a water bath. The mixture was cooled to $28 \pm 2^{\circ} \mathrm{C}$ and centrifuged at 2200 rpm for $15 \mathrm{~min}$ to separate the gel and supernatant. The aqueous supernatant was removed and poured into dish for subsequent analysis of solubility pattern. The weight of the swollen sediment was then determined. The swelling power was calculated as the weight of the gel divided by the original weight of the flour. The supernatant liquid $(5 \mathrm{~mL})$ was poured into a tarred evaporating dish and dried to a constant weighed in air oven at $100^{\circ} \mathrm{C}$ for $4 \mathrm{~h}$. Water solubility index was determined from the amount of dried solids obtained after drying the supernatant and was expressed as gram dried solids per gram of sample. The specific heat capacity of the flour samples were evaluated using the Siebel equation

$\mathrm{Cp}=2.094 \mathrm{X}_{\text {fat }}+1.256 \mathrm{X}_{\text {solid }}+4.187 \mathrm{X}_{\text {moisture }}$ where solid $=$ (protein + carbohydrate + Ash) amended by Choi and Okos, [30].

\subsection{Chemical Properties}

The proximate composition were determined in terms of moisture content, crude protein, fat, ash content, and crude fibre according to the standard methods of AOAC [31]. The protein content was obtained by multiplying the nitrogen content by 6.25 (conversion factor) and the carbohydrate content was determined by difference. The total cyanide content was determined by the alkali titration method while the $\mathrm{pH}$ and titratable acidity were determined using the method of AOAC [31].

\subsection{Statistical Analysis}

Means and standard errors of the mean (SEM) of replicate scores were determined and subjected to analysis of variance (ANOVA) using the Statistical Package for Social Statistics (SPSS version 17). Means were separated using The Duncan's New Multiple Range (DNMR) Test [32]. 


\section{Result and Discussion}

\subsection{Physical Properties of Yam, Cocoyam and Plantain Flour Starches}

There is significant difference $(\mathrm{p}<0.05)$ in the Wettability values among the three flour samples. The wettability values ranging from 40.67- 106.67 (seconds) was highest in the plantain flour probably due to its lower moisture content $(5.6 \%)$ and higher average granule diameter $(0.46 \mu)$. These Wettability values were higher than the value of 42.5 (seconds) reported for D. rotundata [33] and 27-35 (seconds) for D.alata flours [34] of similar products, but lower than 135 - 148 (seconds) for soy-melon 'gari' [35]. This means these flours are denser and would sink in water more than those reported. Wettability also provides a useful indication of the degree to which dried flour is likely to possess instant characteristics which is aided by high porosity. A higher porosity $(35.83 \%)$ and Wettability (106.67secs) were observed in plantain flour with the least moisture content (Table 1) while cocoyam with the highest moisture content also had the least value for porosity (34.83\%) and Wettability (40.67secs). Porosity is an important physical property characterizing the texture and the quality of dry and intermediate moisture foods [36]. It is also an important parameter in predicting diffusion properties of cellular foods [37]). Porosity was lower in the cocoyam flour $(34.83 \%)$ than those of plantain and yam samples (35.63 $35.83 \%$ ) but significantly different from those of cocoyam flour. This is in agreement with Kassama et al. [38] who modeled porosity as a linear function of moisture content. The higher the moisture content, the higher the porosity. Moisture content reduced as drying proceeds, this result in more air space generation in a food material thereby increasing its porosity. Angle of repose of the samples is a function of smoothness, roundness, finess and stickiness of the particles. When the particles are smooth and round, the angle of repose will be low, however for very fine and sticky materials the value is high [17]. Angle of repose, a parameter used in conveyor and discharges design was observed to be highest for plantain $\left(35.67^{\circ}\right)$ and lowest $\left(29.60^{\circ}\right)$ for cocoyam flour. Angle of repose is also a function of both particle size and moisture content. Materials with large particle size give lesser angle of repose likewise, materials with high moisture content result in lesser angle of repose, this account for the lesser angle of repose given by cocoyam $\left(29.60^{\circ}\right)$. Angle of repose is a useful parameter for optimum design of hoppers. The inclination angle of hopper wall should be larger than the grain angle of repose to ensure the continuous flow of grain by gravitational force [39]. No significant difference $(p>0.05)$ was observed in both the packed and the loose bulk densities in the flours but the packed bulk densities were consistently higher in all the three samples. This means that more quantity of supplemented gari can be packed than the control for the same specific volume [40].

There was a significant difference $(\mathrm{p}<0.05)$ in the average particle size among the three samples which was highest in the yam sample $(210.95 \mu \mathrm{m})$ and lowest in the cocoyam sample $(200.47 \mu \mathrm{m})$. Average particle size which is an indication of the minimum energy required to disintegrate the food material revealed that the yam flour which had the highest hence yam requires the highest energy.

There was significant difference $(p<0.05)$ in the amylose contents of the three samples; which could be as a result of the amylose/amylopectin ratio of the samples. The water holding capacities and the swelling index were higher in the yam $\quad(174.60 \% \mathrm{~g} / \mathrm{g}, \quad 1.26 \mathrm{v} / \mathrm{v})$ and cocoyam samples $(170.67 \% \mathrm{~g} / \mathrm{g}, 1.17 \mathrm{v} / \mathrm{v})$ respectively; while the reconstitution index was highest in the yam flour $(4.17 \mathrm{v} / \mathrm{v})$ followed by that of plantain $(3.89 \mathrm{v} / \mathrm{v})$. This means that yam and plantain flours will imbibe more water in swelling than cocoyam flour while both yam and plantain flour will reconstitute better when reconstituted with hot water. This is important in the reconstitution of yam and plantain flours in hot water to produce yam and plantain fufu dough. The highest value $(27.97 \mathrm{~mm})$ for gel strength of cocoyam flour shows that it gave the softest dough of all the three flours while yam with $(14.40 \mathrm{~mm})$ gave the hardest dough upon reconstitution.

Table 1. Physical properties of Yam, Cocoyam and Plantain Flour samples

\begin{tabular}{cccc}
\hline & Cocoyam & Yam & Plantain \\
\hline Wettability (seconds) & $40.67 \pm 0.58^{\mathrm{c}}$ & $47.67 \pm 1.15^{\mathrm{b}}$ & $106.67 \pm 6.11^{\mathrm{a}}$ \\
Porosity $(\%)$ & $34.83 \pm 0.29^{\mathrm{b}}$ & $35.63 \pm 0.29^{\mathrm{a}}$ & $35.83 \pm 0.29^{\mathrm{a}}$ \\
Angle of Repose $(\mathrm{o})$ & $29.60 \pm 1.00^{\mathrm{c}}$ & $33.33 \pm 0.58^{\mathrm{b}}$ & $35.67 \pm 1.53^{\mathrm{a}}$ \\
Packed Bulk Density $\left(\mathrm{g} / \mathrm{dm}^{3}\right)$ & $0.72 \pm 0.02^{\mathrm{a}}$ & $0.73 \pm 0.06^{\mathrm{a}}$ & $0.69 \pm 0.02^{\mathrm{a}}$ \\
Loose bulk Density $\left(\mathrm{g} / \mathrm{dm}^{3}\right)$ & $0.56 \pm 0.09^{\mathrm{a}}$ & $0.53 \pm 0.09^{\mathrm{a}}$ & $0.53 \pm 0.09^{\mathrm{a}}$ \\
Average Particle Size $(\mu \mathrm{m})$ & $200.47 \pm 1.27^{\mathrm{c}}$ & $210.95 \pm 0.91^{\mathrm{a}}$ & $204.31 \pm 1.29^{\mathrm{b}}$ \\
Reconstitution Index $(\mathrm{v} / \mathrm{v})$ & $2.09 \pm 0.23^{\mathrm{b}}$ & $4.17 \pm 0.37^{\mathrm{a}}$ & $3.89 \pm 1.38^{\mathrm{a}}$ \\
Swelling Index $(\mathrm{v} / \mathrm{v})$ & $1.17 \pm 0.02^{\mathrm{a}}$ & $1.26 \pm 0.06^{\mathrm{a}}$ & $1.05 \pm 0.02^{\mathrm{b}}$ \\
Water Holding Capacity $(\% \mathrm{~g} / \mathrm{g})$ & $170.67 \pm 5.12^{\mathrm{a}}$ & $174.60 \pm 9.3^{\mathrm{a}}$ & $164.83 \pm 5.82^{\mathrm{b}}$ \\
Average Granule Diameter $(\mu)$ & $0.24 \pm 0.05^{\mathrm{b}}$ & $0.44 \pm 0.07^{\mathrm{a}}$ & $0.46 \pm 0.03^{\mathrm{a}}$ \\
Gel Strength (mm) & $27.97 \pm 0.21^{\mathrm{a}}$ & $14.40 \pm 0.2^{\mathrm{c}}$ & $24.63 \pm 0.12^{\mathrm{b}}$ \\
Amylose $(\%)$ & $25.53 \pm 0.12^{\mathrm{c}}$ & $35.92 \pm 0.04^{\mathrm{b}}$ & $33.24 \pm 0.04^{\mathrm{a}}$ \\
\hline Values are means of replicate readings & & \\
\pm Standard error of Mean & &
\end{tabular}




\subsection{Thermal Properties of Yam, Cocoyam and Plantain Flour Starches}

Table 2 shows the behavior of the samples under thermal treatments. There was increase solubility of all the samples with increase in temperature. The increase in solubility with temperature is attributed to the swell in granule over a range of temperature. The solubility of starch is believed to be affected by factors such as inter-associative forces, swelling power, presence of surfactants and other associative compounds [41]. Ruales, et al., [42] explained that there was a rapid swelling of starch granule at gelatinization temperature $\left(72-81^{\circ} \mathrm{C}\right)$ which was probably responsible for high swelling power and solubility observed between $60^{\circ} \mathrm{C}$ and $90^{\circ} \mathrm{C}$ compared to that observed at $45^{\circ} \mathrm{C}$ and $60^{\circ} \mathrm{C}$. As a direct result of granule swelling, there is an increase in starch solubility [43]. Cocoyam has the highest solubility at $45^{\circ} \mathrm{C}$ and the highest also at $90^{\circ} \mathrm{C}$, the same thing was observed in its swelling power. Yam gave the least value for solubility and this may be attributed to its low swelling power (Table 3 ) which results from its high amylose content (Table 2). High amylose content has been linked to low swelling power due to greater reinforcement of the internal network by amylose molecules [45].

Generally, it was observed that solubility increased with reduction in amylase content (Table 2). There was no significant difference $(\mathrm{p}<0.05)$ in the solubility of the three samples at $60^{\circ} \mathrm{C}$. Amylose is reported to be the main component which leaches into the surrounding medium to increase. It was also observed that swelling power increased with temperature which may be attributed to swell in granule over a range of temperature.

Cocoyam exhibited the highest swelling power at temperatures of $45^{\circ} \mathrm{C}$ and $90^{\circ} \mathrm{C}$ while yam exhibited the least. There was significant difference $(p<0.05)$ in the swelling power at all temperatures. The relatively low swelling power of yam could be attributed to its high amylose content (Table 2). High amylose content has been linked to low swelling power due to greater reinforcement of the internal network by amylose molecules [44]. In a study on yam, Riley et al.
[45] observed higher swelling power in yam varieties with lower amylose content. According to Jane and Chen [13], amylopectin contributes to granule swelling while amylose and lipids inhibit it. Highly associated starch granules with an extensive and strongly bonded structure also exhibit resistance toward swelling. Swelling and solubility provide evidence of the magnitude of interaction between starch chains within the amorphous and crystalline domains or provide evidence of non-covalent bonding between molecules within the starch granules. The extent of this interaction is influenced by the amylose to amylopectin ratio in terms of molecular/weight distribution, degree and length of branching and conformation $[43,44]$. Starches with more phosphate groups, such as potato starch, are more prone to swelling [44]. Starch phosphate monoesters carry negative charges and repel one another, thereby reducing inter chain associations. This increases the level of hydrated molecules. Formation of amylose-lipid complexes could also restrict swelling and solubilization. Yam species exhibit lower and single stage swelling curves unlike cassava which displays two. This is attributed to the more highly ordered internal arrangement in the granules of yam. Differences in swelling power and solubility between samples could be due to differences in starch composition and granule organization [43]. From the results of the specific heat capacities of the samples, it was observed that cocoyam has the highest value followed by yam and plantain. This could be attributed to the differences in the chemical composition of the samples since the value of the specific heat capacity depends on the values derived from their chemical composition. specific heat of a material (cp), which is the amount of heat needed $(\mathrm{kJ})$ to increase the temperature of a unit mass $(\mathrm{kg})$ by one degree $\left({ }^{\circ} \mathrm{K}\right)$.It can be observed from the Table 5 that plantain sample has the highest moisture content $(37.50 \%)$ and it exhibited the lowest Heat capacity of $168.33 \mathrm{~kJ} / \mathrm{kgK}$. Siebel argued that the specific heat of the food can never be greater than the sum of the specific heat of the solid matter and water since water in food materials exists side by side with the solid matter without any heat producing chemical reactions [33].

Table 2. Thermal properties of Yam, Cocoyam and Plantain Flour Starches

\begin{tabular}{cccc}
\hline Measured variables & Cocoyam & Yam & Plantain \\
\hline \multicolumn{4}{c}{ Swelling power $(\mathrm{g} / \mathrm{g})$} \\
\hline $450 \mathrm{C}$ & $3.65+0.04 \mathrm{a}$ & $3.43+0.29 \mathrm{a}$ & $2.77+0.09 \mathrm{~b}$ \\
$600 \mathrm{C}$ & $3.88+0.04 \mathrm{a}$ & $4.11+0.03 \mathrm{a}$ & $3.29+0.29 \mathrm{~b}$ \\
$900 \mathrm{C}$ & $15.46+0.13 \mathrm{a}$ & $11.71+0.39 \mathrm{c}$ & $13.38+0.56 \mathrm{~b}$ \\
\hline \multicolumn{4}{c}{ Solubility $(\mathrm{g} / \mathrm{g})$} \\
\hline $450 \mathrm{C}$ & $8.23+0.08 \mathrm{a}$ & $6.99+1.61 \mathrm{ab}$ & $5.32+0.33 \mathrm{~b}$ \\
$600 \mathrm{C}$ & $11.41+1.57 \mathrm{a}$ & $8.67+2.66 \mathrm{a}$ & $9.17+0.65 \mathrm{a}$ \\
$900 \mathrm{C}$ & $19.30+1.45 \mathrm{a}$ & $10.98+1.30 \mathrm{~b}$ & $13.30+1.55 \mathrm{~b}$ \\
\hline Specific heat capacity(kJ/kgK) & $174.37+0.37 \mathrm{~b}$ & $173.28+0.97 \mathrm{a}$ & \\
\hline & &
\end{tabular}




\subsection{Pasting Properties of Yam, Cocoyam and Plantain Flour Starches}

Table 3 shows the pasting properties of the Yam, Cocoyam and Plantain Flour Starches. The behaviour of flour/starch during cooking, gelatinization and pasting has been linked to its quality and suitability of use [17]. Pasting properties are therefore an important quality index in predicting the behavior of flour paste during and after cooking. The parameters recorded for each flour sample during the pasting cycle were pasting temperature, peak viscosity, viscosity at $95^{\circ} \mathrm{C}$ (trough), viscosity at constant $95^{\circ} \mathrm{C}$ (breakdown), viscosity at $50^{\circ} \mathrm{C}$ (final viscosity) and viscosity at constant $50^{\circ} \mathrm{C}$ (setback).. Significant variations $(\mathrm{p}<0.05)$ were observed among the varieties in Peak Viscosity, Trough, Final Viscosity and Set Back values. When starch is heated in an aqueous environment, it undergoes a series of changes known as gelatinization which is characterized by swelling and change in viscosity. Viscosity is low at the beginning of gelatinization but it increases as the temperature increases. The temperature at which the viscosity of the stirred starch/flour slurry begins to rise is the pasting temperature. It is an index characterized by an initial change in viscosity due to the swelling of starch [46]. It gives an indication of the minimum temperature required to cook a given flour/starch sample and this has implications for the suitability of other food components (with different gelatinization temperature) in a food formula [28]. Pasting temperature was comparatively higher in cocoyam than the other samples. Values ranged from 48.01 $-49.51^{\circ} \mathrm{C}$ with highest value in the cocoyam sample. Peak time ranged from $4.97 \mathrm{~min}$ to $5.15 \mathrm{~min}$ while plantain had the highest value.

Higher pasting temperature values $\left(80.0-87.0^{\circ} \mathrm{C}\right)$ have however been reported for some different yam species in the literature [47, 48]; but Otegbayo et al. [48] reported comparatively lower pasting temperatures for $D$. rotundata. The slightly higher pasting temperatures and peak time for cocoyam suggest that it has a higher gelatinization temperature and a longer cooking time than the plantain and yam flours. For technical and economic reasons, starches/flours with low pasting time and temperature may be preferred when all other properties are equal.

Peak viscosity is the maximum viscosity attained by the paste during the heating cycle (i.e., from $50^{\circ} \mathrm{C}$ to $95^{\circ} \mathrm{C}$ ) due to starch granules swelling and leaching out of the soluble components into the solution. It reflects the ability of starch granules to swell freely before their physical breakdown [43] and often correlates with product quality. Peak viscosity ranged between 272.47 RVU lowest for cocoyam and 373.87 RVU highest for yam. The relatively longer time taken for yam flour to paste further indicates stronger bonding forces in their starch granules. Yam starches generally have some level of resistance to swelling which is more pronounced in some D. alata varieties. Rickard et al. [49] reported that cassava starch has a high peak viscosity because it exhibits a high degree of swelling. According to Rickard et al. [49] and Singh et al.[43] pasting viscosities and swelling are positively related. The higher the swelling power of a sample, the higher the pasting viscosities. High peak viscosity contributes to good texture of pounded yam, which basically depends on high viscosity and moderately high gel strength [48].

Table 3. Pasting Properties of Yam, Cocoyam and Plantain Flour Starches

\begin{tabular}{cccc}
\hline & Plantain & Cocoyam & Yam \\
\hline Peak viscosity (RVU) & $272.47 \pm 2.66$ & $377.83 \pm 5.00$ & $322.88 \pm 3.62^{\circ}$ \\
Trough (RVU) & $193 \pm 1.04$ & $327 \pm 1.83$ & $228 \pm 1.06{ }^{\circ}$ \\
Breakdown (RVU) & $79.52 \pm 3.69$ & $50.50 \pm 7.65$ & $95.21 \pm 6.96$ \\
Final viscosity (RVU) & $302.83 \pm 1.25$ & $457.34 \pm 7.12$ & $380.09 \pm 5.08$ \\
Setback (RVU) & $110 \pm 0.21$ & $130 \pm 5.9$ & $152 \pm 5.5$ \\
Peak Time (min) & $5.09 \pm 0.04$ & $5.15 \pm 0.07$ & $4.97 \pm 0.11$ \\
Pasting Temperature $\left({ }^{\circ} \mathrm{C}\right)$ & $49.51 \pm 0.05$ & $48.01 \pm 0.05$ & $48.56 \pm 0.60$ \\
\hline
\end{tabular}

Values are means of 3 replicate readings

\pm Standard error of Mean

$a, b, c *$ Means followed by different letters in a row are significantly different $(\mathrm{P}<0.05)$

Table 4. Proximate Compositions of Yam, Cocoyam and Plantain Flours (\%)

\begin{tabular}{ccccccc}
\hline Sample & Protein & Moisture & Ash & Fat & Fibre & Carbohydrate \\
\hline Cocoyam & $2.5+0.07 \mathrm{~b}$ & $8.4+0.69 \mathrm{a}$ & $2.82+0.04 \mathrm{a}$ & $1.53+0.11 \mathrm{a}$ & $1.05+0.04 \mathrm{a}$ & $83.69+0.75 \mathrm{~b}$ \\
Yam & $3.2+0.05 \mathrm{a}$ & $7.9+0.12 \mathrm{~b}$ & $2.23+0.18 \mathrm{~b}$ & $1.24+0.06 \mathrm{a}$ & $1.07+0.04 \mathrm{a}$ & $84.27+0.04 \mathrm{~b}$ \\
Plantain & $2.07+0.02 \mathrm{c}$ & $5.6+1.4 \mathrm{c}$ & $1.93+0.05 \mathrm{c}$ & $1.54+0.25 \mathrm{a}$ & $0.88+0.04 \mathrm{~b}$ & $88.34+1.22 \mathrm{a}$ \\
\hline
\end{tabular}

Values are means of 3 replicate readings

$\pm=$ Standard error of Mean

a,b,c * Means followed by different letters in a column are significantly different $(P \leq 0.05)$ 


\subsection{Proximate Composition of Yam, Cocoyam and Plantain Flour Starches}

Table 4 shows the proximate compositions of yam, cocoyam and plantain flours. The 48 hours drying reduced the moisture content of the various samples to a range of 5.6 $8.4 \%$ with the plantain flour having the lowest value. Moisture removal by heat generally helps to increase concentration of nutrients in food and can make some nutrients more available. It as well increases the porosity of the food material. Significant differences existed $(p<0.05)$ in the percentage protein contents of cocoyam flour and that of others, and yam having the highest value (3.2\%), followed by cocoyam $(2.5 \%)$, while plantain has the least value of $2.07 \%$ although with the highest carbohydrate content of about $88.34 \%$. The values obtained for yam similar to the value reported by Jimoh and Olatiloye [50] while the value for cocoyam was lower than those reported by Ajewole [51] and Oladeji et al, [52]. This might have been due to variations in chemical composition of different varieties. However, it can be seen that the drying helps to increase the protein content when compared with the fresh sample by concentrating the nutrients in the dried products. Ash content is a reflection of mineral status, even though contamination can indicate a high concentration in a sample. Values ranged between $1.93 \%$ and $2.82 \%$ with the lowest value obtained for plantain flour and the highest for cocoyam flour. Significant difference was observed at $(\mathrm{p}<0.05)$ among the samples which could be attributed to the type of soil from which it was harvested, moisture content and the level of maturity of the crop [9]. The carbohydrate content of the three samples was generally high which makes them an energy giving food. Plantain has the highest carbohydrate content with $88.34 \%$ while cocoyam has the lowest content with $83.69 \%$. When compared with the fresh sample, which is the reference point, it can be seen that there is an increase in the carbohydrate content. This increase can be associated with the fact that removal of water from foods helps to concentrate the nutrients. No significant difference $(p<0.05)$ was observed among the fat contents of the samples.

\section{Conclusions}

It has been shown from this study that on the average, most of the physico-chemical characteristics evaluated were relatively higher in plantain than those of yam and cocoyam. There were higher carbohydrate $(88.34 \%)$ and fat $(1.54 \%)$ contents, higher wettability (106.67secs), porosity (35.83), angle of repose $\left(35.67^{\circ}\right)$, average granule diameter $(0.46 \mu)$, break down (95.21 RVU) and set back (152 RVU). However, protein $(2.07 \%)$, moisture content $(5.6 \%)$, ash $(1.93 \%)$, fibre $(0.88 \%)$, swelling index (1.05), water holding capacity $(164.83 \mathrm{~g} / \mathrm{g})$ and peak time (48.56 RVU) were comparatively lower. Cocoyam equally had appreciable contents of moisture and ash. Based on the physicochemical and pasting characteristics of these products, they could be processed to flour for use in diet formulations. Swelling power and solubility increased with temperature with all flour samples with cocoyam giving the highest value. The measured physicochemical properties in conjunction with pasting properties of the samples suggest the presence of strong bonding forces within their starch granules. The relatively higher pasting temperatures required, and the lower pasting viscosities make cocoyam suitable for producing weaning foods and other products that require low viscosity. Pasting properties of cocoyam revealed relatively higher thermal and mechanical stability which will make it a good ingredient for processed foods, especially those that require thermal sterilization. The higher peak viscosity for yam contributes to the good texture of dough produced from yam in form of "pounded yam" and "amala" (local staple diets) from yam flour, which basically depends on high peak viscosity and moderately high gel strength.

\section{REFERENCES}

[1] G. J. Scott, Rosegrant M. and Ringler, C. "Roots and Tubers for the 21st Century: Trends, projections and policy options", Food Agriculture and the Environment Discussion 31. International Food Policy Research Institute (IFPRI) and International Potato Centre (CIP), (2000), Washington, D.C, U. S. A.

\section{[2] FAO (2004). Statistics Series No 95 FAO, Rome}

[3] I. B. Oluwalana,. and Oluwamukomi, M. O. Proximate composition, rheological and sensory qualities of plantain (Musa parasidiaca) flour blanched under three temperature regimes African Journal of Food Science, (2011) 5(14): 769-774.

[4] P. O. Ogazi, "Storage and Processing of Plantain", In: Invited Lecture at the Plantain Production Training Course, (1983), IITA, Ibadan, Nigeria,

[5] P. O. Ogazi, and Jones, M.C. "Pilot Scale Dehydration of Plantain Pulp for Flour Production using Cabinet Dryer". Nigeria Food Journal. (1990), 8: p. 74-77

[6] O. A. Ajayi, and Madueke, L. U. "A study of stored yam (Dioscorea cayenensis) as affected by the ventilation of the storage locations", Journal of Science Food and Agriculture, (1990), 50: 257-260.

[7] D. G. Coursey, and Booth, R. H. "Post-harvest problems of non-grain staples", .Acta Horticulturae, (1997), 53, 22-33.

[8] B. A. Alabadan, "Assessment of storage losses in roots and tubers in Niger State, Nigeria", African Journal of Root and Tuber Crops, (2002), 5(1): 49-52.

[9] A. U. Osagie, "The Yam in Storage", Postharvest Research Unit, University of Benin, Nigeria. In: Nutritional quality of plant foods, (1992), Department of biochemistry, University of Benin, Benin City Nigeria.

[10] S. R. Barquar, and Oke, O. L. "Mineral constituents of Nigerian yams", Nutr.Rep.Int., (1977), 15 (3): 265-272.

[11] S. N. Moorthy, "Tuber crop starches", Technical bulletin series 18, (1994), Central Tuber Crops Research Institute, Thiruvananthapuram, Kerala, India. 
[12] F. H. G. Peroni, Rocha, T. S. and Franco, C. M. L. "Some structural and physicochemical characteristics of tuber and root starches", Food Sci. Tech Int., (2006), 12 (6): 505-513.

[13] J. Jane, and Chen, J. F. "Effect of amylose molecular size and amylopectin branch chain length on paste properties of starch", Cereal Chemistry, (1992), 69, 665.

[14] R. P. Ellis, Cochrane, M.P; Dale, M.F.B; Duffus, C.M; Lynn, A; Morrison, I.M; Prentice, R.O.M; Swanston, J.S and Tiller, S.A., "Starch production and industrial use", Journal of Sci. Food Agric., (1998), 77, 289 - 311.

[15] F.A.O., Food and Agriculture Organisation. "Action Programme for the Prevention of Food Losses, Improving Post-harvest Handling, Storage and Processing of Root and Tuber Crops", (1990), Rome, Italy.

[16] S. N. Moorthy, "Physicochemical and functional properties of tropical tuber starches", Starch/Starke, (2002), 54, 559-592.

[17] J. Chen, and Lu, S., "Relationship between grain physicochemical characteristics and flour particle size distribution for Taiwan rice cultivars", Journal of Food and Drug Analysis, (2004), 12, 52-58.

[18] S. Sefa-Dedeh; Cornelius, B. and Afoakwa, E. O., "Effect of Fermentation on the quality characteristics of nixtamatized corn", Food Research International, (2003), 36, 57-64.

[19] J. T. Jane; S. Kasemsuwan; Leas, H. Zobel, and J. F. Robyt.. "Anthology of starch granule morphology by scanning electron microscopy", Starch, (1994) 46, 121-129.

[20] U. J. Ukpabi and Ndimele, C., "Evaluation of garri production in Imo state, Nigeria. Nigeria", Nig. Food Journal, (1990), 8, 105-110.

[21] E. B Banigo, and Akpapunam, M. A "Physicochemical and nutritional evaluation of protein enriched fermented maize flour", Nig. Food J. (1987), 5, 30-36

[22] B. I. Armstrong; Stanley, D.W. and Maurice, T.J. In: Functionality of Protein Structure; Ed. Akiva Pour-ELACS Symposium Series 92, (1979), American hemical Society, Washington, D.C.

[23] D. Geldart,. Single "Particles, Fixed and Quiescent Beds", In: Gas Fluidization Technology. Wiley Interscience Publication, (1986), 15-33, 65-69

[24] D. G. Medcalf, and Gilles, K. A. "Wheat Starches" 1n: Comparison of Physicochemical properties", Cereal Chemistry, (1998), 42, 538-568.

[25] F. A. Numfor, and Noubi, L. "Effect of full-fat soya bean flour on the quality and acceptability of fermented cassava flour", Food and Nutrition Bulletin., (1995), Volume 16, Number 3,

[26] J. Atkinson, "An Introduction to the Mechanics of Soils and Foundations", McGraw Hill Book Company, (1993), p. 51

[27] Newport Scientific, “Applications manual for the Rapid visco TM analyzer Using Thermo cline for windows", Newport Scientific Pty Ltd., 1/2 Apollo Street, Warriewood NSW 2102, Australia, (1998), p. 2-26.

[28] I. A. Farhat, Oguntona, T. and Neale, J. R.. "Characterisation of starches from West African yams", .J. Sci. Food Agric., (1999), 79, 2105-2112.
[29] S.U. Sasaki, Yasui, T. \& Matsuki, J., "Influence of non-starch polysaccharides isolated from wheat flour on gelatinization and gelation of wheat starches". Food Hydrocolloids, (1998). 14, 295-303."

[30] Y. Choi, and M. Okos., "Thermal Properties of Liquid Foods-Review". In: Physical and Chemical Properties of Food. M.R. Okos (ed.). St. Joseph, MI: American Society of Agricultural Engineers, (1986).

[31] AOAC, "Official methods of analysis of the Association of Official Analytical Chemists", vol. II, 15th ed., (1990), Sec. 985.29.

[32] R. Steel, Torrie, J. and Dickey, D., "Principles and Procedures of Statistics: A Biometrical Approach", 3rd ed., McGraw Hill Book Co., New York, USA, (1997)

[33] H.O. Udensi and J.C. Okaka, "Predicting the effect of particle size profile, blanching and drying temperature on the dispersibility of yam flour", Global J. Pure Appl. Sci., (2000), 6, 589-592.

[34] H.O. Udensi, Oselebe and O.O. Iweala. "The Investigation of Chemical Composition and Functional Properties of Water Yam (Dioscorea alata): Effect of Varietal Differences", Pakistan Journal of Nutrition, (2008), 7 (2): 342-344,

[35] M. O. Oluwamukomi,. and Jolayemi O. Physicochemical Thermal and Sensory Properties of Soy-melon enriched gari semolina from cassava. Agricultural Engineering International: the CIGR E-journal, (2012). 14 (3): 105-116.

[36] V. T Karathanos. and Saravacos G.D., Porosity and pore size distribution of starch materials. J. Food Eng., (1993) 18, 259-280.

[37] M. D. Abramoff, P. J. Magelhaes, S. J. Ram. Image processing with Image. J, Biophot.Int. , (2004), 11:36.

[38] L.S. Kassama, Ngadi, M.O., and Raghavan, G.S.V. Structural and instrumental evaluation of textural properties of meat patties containing soy protein.International Journal of Food Properties, (2003), 6, 519-529.

[39] M., H Sadeghi,. Ashtiani Araghi, A. Hemmat,. Physico-mechanical properties of rough rice (Oryza sativa L.) grain as affected by variety and moisture content Agric Eng Int: CIGR Journal Open access at http://www.cigrjournal.org (2010). Vol. 12, No.3 129

[40] T. N Fagbemi Effect of blanching and ripening on functional properties of Plantain (Musa aab) Flour. Plant Food for Human Nutrition (1999), 54: 261 - 269.

[41] S Sibanda, Sibanda S, Sychawska B. A comparative study of wild yam starch from Dioscorea schimperiana. Journal of Applied Science South Africa (2000), 6: 79-86.

[42] J . Ruales, Valensia, S. and Nair, B. Effect of processing on the physicochemical characteristics of quinoa flour (Chenopodium quinoa, Wild). Starch (1993), 46 (1): 13-19.

[43] N. Singh, Singh, J., Kaur, L., Sodhi, N. S. and Gill, S.B., "Morphological, Thermal and Rheological Properties of Starches from different botanical sources", Food Chem. (2003), 81, 21-231.

[44] R. Hoover, "Composition, molecular structure and physicochemical properties of tuber and root starches", Carbohydrate polymers, (2001), 45, 253-267.

[45] C. K. Riley, Wheatley AO, Hassan I, Ahmad MH, Morrison E 
St. Y, Asemota H. N., "In vitro digestibility of raw starches extracted from five yam (Dioscorea spp.) species grown in Jamaica", Starch/Starke, (2004), 56, 9-73.

[46] E. O. Afoakwa, and Sefa-Dedeh, S., "Viscoelastic properties and changes in pasting characteristics of trifoliate yam (Dioscorea dumetorum) starch after harvesting", Food Chemistry, (2002), 77, 203-208.

[47] D. A. Sahorè, Amani, N. G. and Nemlin, G. J., "The properties of starches from some Ivory Coast wild yam (Dioscorea) species", Tropical Science, (2005), 45 (3), $122-125$

[48] B. Otegbayo, Aina, J., Asiedu, R., and Bokanga, M., "Pasting characteristics of fresh yams (Dioscorea spp.) as indicators of textural quality in a major food product.-'pounded yam', Food Chemistry, (2006), 99, 663-669.
[49] J. E. Rickard, Asoako, M. and Blanshard, J. W. V., "The Physicochemical Properties of Cassava Starch", Trop. Sci., (1991), 31, 189-207.

[50] K.O. Jimoh, Olatidoye OP Evaluation of Physicochemical and Rheological characteristics of soybean fortified yam flour. J. Appl. Biosci. (2009), 13:703-706.

[51] A.I. Ajewole.. Enrichment of Pregelatinized Cocoyam Flour with melon seeds protein Concentrate as an Instant food gel. J. A. T. (1994). 5(2): 28-32

[52] B. S Oladeji, , Akanbi, C. T and Gbadamosi, S. O. Comparative studies of physico-chemical properties of yam (Discorea rotundata), cocoyam (Collocasia taro), breadfruit (Artocapus artilis) and plantain (Musa parasidiaca) instant flours. African J of Food Science. (2013), 7(8): 210-215. 